\title{
Reflexive Governance for Infrastructure Resilience and Sustainability
}

\author{
Mattia Ferrari 1,2 \\ 1 European Institute for Innovation-Technology e.V., 73525 Schwäbisch Gmünd, Germany; \\ mat.ferrari2@gmail.com \\ 2 Centre for Studies on European Economy (AIM), Azerbaijan State University of Economics (UNEC), \\ Baku 1001, Azerbaijan
}

Received: 25 October 2020; Accepted: 3 December 2020; Published: 7 December 2020

\begin{abstract}
Infrastructure development is one of the areas most in need of climate-resilient and friendly investments. The COVID-19 pandemic will increase government spending in this direction. This paper demonstrates how the principles of reflexive governance are key to unlock the full potential of such investments. By establishing an adaptive and redundant institutional capacity in the provision of public services, reflexive governance can enable a successful path towards climate resilience and sustainability.
\end{abstract}

Keywords: reflexive governance; climate change; infrastructure; urban resilience; sustainability

\section{Introduction}

Nowadays infrastructure networks are at an increasing risk of disruption due to extreme and unpredictable weather events caused by climate changes. These infrastructures must provide a continuous, safe and reliable performance to satisfy the demand coming from several stakeholders [1]. Due to the high degree of network interdependencies and market connectivity [2], the United Nations Office for Disaster Risk Reduction (UNDDR) estimated that the economic and environmental damages due to service disruptions could reach USD 415 billion within the next 15 years [3].

Financing climate-resilient infrastructure is particularly relevant in the least developed countries as this is essential to achieve inclusive economic growth [4]. The Global Climate Risk Index 2015 indicated how 9 out of the 10 most-affected countries by climate events between 1994 and 2013 were low-income or middle-income countries [5]. A study from the World Bank reported how investments in climate-resilient hydropower infrastructures in Africa could lead to an increase in revenues of 20 to 140 per cent; on the other hand, inadequate planning could result in revenue losses ranging from 5 to 60 per cent [6].

The COVID-19 pandemic will increase government spending for economic recovery plans, which will include infrastructure development. This offers the opportunity to smooth the path towards 2030 Sustainable Development Goals (SDGs), also by investing in climate-resilient and sustainable infrastructure provision [7]. For instance, the required financing for transport infrastructure is estimated to be USD 440 billion annually to achieve the 2030 SDGs [8].

The principles of reflexive governance are key to unlock the potential of such investments. Reflexive governance is defined as the ability to go through complex processes of socio-technical change by developing innovative approaches, in a perspective of participation, probing and collective learning [9]. An example is a collaborative approach to environmental risk management, such as waste banks in developing countries [10]. This paper demonstrates how reflexive governance can establish an adaptive and redundant institutional capacity in the provision of public services, enabling a successful 
path towards climate resilience and sustainability. The close relationship between resilience and sustainability was highlighted by previous literature (see Elmqvist et al. [11] for a literature review).

The types of infrastructure considered for the analysis are those network components operating at the community level (distribution of electricity and water, collection and recycling of waste and local roads) for two reasons. First, the principles of collaboration, probing and collective learning are highly applicable at a local scale. Second, cities are responsible for 70 per cent of global greenhouse gas emissions, and 90 per cent of urban areas are located on climate-vulnerable coastlines [11].

This paper contributes to the discussion on the lack of adequate governance arrangements in the face of future global crises. In particular, it tries to provide an answer to the question posed by Brousselle et al. [12] of which elements of recovery plans are capable to reduce future vulnerabilities. This paper proposes reflexive governance as a tool to sustain resilient, sustainable and inclusive development in the upcoming decades. Supporting reflexive, resilient and inclusive societies is a prerequisite to achieving sustainable development [13-15].

Section 2 introduces the concept of resilience applied to infrastructure. It focuses on critical infrastructure because this category of assets is considered the most in need of a climate-resilient policy. Critical infrastructure can serve as a reference for investigating resilience interventions in the area of infrastructure. Section 3 explains the notion of reflexive governance, introducing the model of transition management (TM) and the concept of better regulation. Section 4 illustrates the application of reflexive governance in structuring resilient infrastructure service provision. Section 5 highlights the positive implications for sustainable and inclusive growth. Section 6 discusses the applicability of such recommendations.

\section{Critical Infrastructure Resilience}

The concept of critical infrastructure has been defined differently over time and across institutions. Overall, critical infrastructures are identified as those networks (or components) which are strategic for the provision of basic public services and for national security (such as energy, transport, water, telecommunications and waste management). At the EU level, this definition has been expanded to account for the increasing network interconnectivity across Member States. A European critical infrastructure (ECI) exists when the shock has a significant impact on at least two Member States [16].

The notion of critical infrastructure resilience refers to the buffering capacity of such a network to absorb a disturbance while retaining essentially the same functions as before the disruptive shock. It also refers to the network capacity to limit the duration of service interruption, hence minimising the recovery time. The recovery process does not necessarily mean resuming to exactly the prior state before the shock but may involve changing and adapting to new conditions $[17,18]$. Thus, infrastructure resilience has replaced the traditional concept of infrastructure protection, which was characterized exclusively by preventive and protective actions [19].

Governments play a central role in setting the stage for the development of resilient critical infrastructure [20]. Sectoral regulation, through the implementation of financial incentives (compensation to end-users) and non-financial incentives (transparency requirements), must ensure the establishment of acceptable standards of both risk and resilience [2]. For example, imposing compensation mechanisms to end-users in case of service disruption can incentivize operators to invest properly in resilience, while providing them with flexibility in the choice. Transparency requirements could instead create reputational concerns upon operators in case of service disruption.

Governments must also implement mitigation and adaptation policies to reduce the likelihood of the shock and to minimize its magnitude and duration. Such policies must be adopted throughout the whole life cycle of the infrastructure project, from its design and operational phase to retrofitting interventions [21]. The innovation process towards decentralized or autonomous networks (for example, renewable energy production and smart grids, artificial intelligence, big data, etc.) allows for a flexible response to negative events [22]. In order to develop mitigation and adaptation policies, it is necessary to adopt a multi-hazards, multi-sectoral and cross-border approach [23]. In addition, the cascading 
impact effect stemming from the large-scale network interdependency across countries requires sound cooperation (and information sharing) among various stakeholders, including local governments and private operators [22].

In order to ensure fair competition and to avoid opportunistic behaviours, it is necessary to guarantee a fair redistribution of the costs for resilience across stakeholders, requiring agreements on acceptable risks, required investments and compensations [24]. Nowadays, this is difficult because of the presence of complex procurement contracts and ownership structures, such as concession contracts and public-private partnerships (PPPs) [25]. However, the large financing gap in infrastructure provision, tied with increasing costs for resilience, requires the involvement of private capitals [26-28].

\section{The Notion of Reflexive Governance}

Infrastructure sectors have identified their own governance, i.e., the capacity to shape and transform itself, as a major concern [9]. As a response, the notion of reflexive governance was proposed to tackle challenges such as the transition to clean and/or decentralized energy production [29]. Reflexive governance becomes concerned with its own conditions, perspectives, expectations, knowledge, strategies and dynamics, in order to avoid the assumption of full knowledge in advance [30]. Nowadays, this assumption cannot be valid due to extreme and unexpected weather events. Reflexive governance implies the acknowledgment of participation, deliberation, probing and collective learning as key elements for inducing and navigating complex processes of socio-technical change [31]. Some authors have underlined that the notion of reflexive governance is recalled by the term resilience itself as the ability to thrive on and to adapt to shocks by developing new approaches [32,33].

This dynamic and polycentric model of governance may lead to more effective and sustainable provision of public services [34]. Reflexive governance is widely applied in the context of sustainability as it aims to solve socio-ecological vulnerabilities. To contrast environmental degradation, reflexive governance proposes renewed forms of analysis and design of environmental policy and planning [35], as well as collaborative climate risk management [36,37]. The importance of a collaborative approach to environmental risk governance was recognized by the Aarhus Convention (1999), which established rights to access environmental information and legitimated public participation in environmental decision-making [38].

The model of transition management represents a suitable tool for the adoption of innovative approaches within complex socio-technical systems such as network infrastructures, natural resources and waste, agriculture and housing [39]. TM aims at "influencing the direction and speed of transitions by coordinating and enabling the processes that occur at different levels in a more systemic and evolutionary way" [40]. Rotmans et al. [38] defined TM in a perspective of incrementalism planning by adopting long-term system thinking, back-casting and forecasting. The objectives of TM are to achieve desirable social goals, to avoid serious pitfalls, i.e., strengthening resilience, and to adopt institutional reforms to cope with unfolding patterns of change [39].

The concept of better regulation, adopted by the European Commission, seems an adequate instrument to adopt the notions of reflexive governance and TM through the implementation of concrete actions. These include (i) evidence-based policymaking, (ii) legislative simplification for fit-for-purpose law, (iii) extensive planning, risk and impact assessment, (iv) improved stakeholders consultation and coordination to strengthen mutual capability and (v) transparency [41].

\section{Governance for Resilience}

At present, there are barriers to deliver climate-resilient infrastructure. First, resilient criteria in procurement contracts are not yet the norm. Second, when those criteria are present, they tend to increase the overall costs of an infrastructure project [2]. Furthermore, according to McPhearson [42], the traditional governance for infrastructure resilience has proved to be narrow-minded and not socially optimal, causing local inequity and injustice, driving gentrification, displacing minority and vulnerable groups, etc. Other concerns refer to poor institutional capacity. For example, limited 
administrative and jurisdictional scales, political and sectoral divisions, dysfunctional collaboration, opaque interests and autonomous actors with limited resources [43].

This section proposes reflexive governance as an instrument to establish an adaptive and redundant institutional capacity in order to structure resilient infrastructure service provision. This renewed form of institutional capacity is expected to increase resilience through easily changing and adapting to new conditions and through coordinating the service provision at different levels in an evolutionary way. Given the long-term, large-scale and social nature of infrastructure, enhanced participation of stakeholders and local end-users are capable to trigger self-adjustment mechanisms in case of disruptive shocks, i.e., adaptation policies, in order to change and to adapt to new conditions [44]. This allows to minimize the recovery time of service provision after the negative event and, by definition, improves the overall resilience.

This proposed approach is in line with the works of Kumaraswamy et al. [44] and Junqi [45], who introduced the term public-private-people partnership (4P). The term $4 \mathrm{P}$ was further proposed in the context of urban development [46], sustainable waste management and post-disaster reconstruction [47]. According to Sundararajan and Suriyagoda [27], due to the increasing unpredictability of climate events, it is necessary to introduce an "active" model of governance for risk management in the context of infrastructure development. This implies working proactively together to continuously "collect, identify and assess the likelihood and impacts" of climate events in order to intervene effectively. It can help in the "informed development and implementation of actions/responses through learning" [27].

A practical example is waste banks in developing countries, a collaborative and innovative approach to sustaining a climate-resilient and sustainable waste management infrastructure. This is done through an institutional capacity-building strategy at the local level, involving environmental communication strategy, education and training and partnerships [10]. Community-led initiatives towards recycling can prevent adversities such as homes being buried by landslides of waste dumps, clogging drains causing flood-related disruption of infrastructures, heavy reliance on waste transportation and incineration, waste dispersion due to winter storms and health hazards caused by waste degradation in case of heat waves [48,49].

These collaborative approaches to environmental risk management allow adopting individual or community-based responses. Existing strategies include (i) risk prevention, such as spatial planning and monitoring of watercourse or roads, (ii) protection, such as the construction of flood defence infrastructure and identification of vulnerable groups, (iii) preparedness through emergency response plans and (iv) recovery phase, including insurance schemes and redistribution of reconstruction tasks [34]. The input from local end-users can vary between co-funding or co-delivery of material and intellectual resources (time, technical skills, knowledge and machinery) [50]. In addition, flexible contracts for the co-management of urban commons have been proposed [51,52]. In line with the idea of knowledge co-production [12], ICT (Information and Communications Technology) can shape a new role for citizens in risk management activities, for instance, in the building of citizen observatories [53]. Global movements in this direction are already present, such as the Global Resilient Cities Network, which implements social innovation and urban experiments to bridge the gap in urban resilience strategies [54].

All the above supports the mandate of multilateral development banks (MDBs) in facilitating global compliance with the climate-resilient infrastructure agenda [55]. Such institutions are in the position to develop frameworks of agreement with national, regional and local stakeholders to promote the principles of reflexive governance. MDBs are currently at the forefront of the use of climate risk screening tools [2]. The International Finance Corporation (IFC), focusing on the private sector in the least developed countries, defines private sector responsibilities for managing environmental and climate risks. It also identifies appropriate mitigation and adaptation policies, including the sustainable use of natural resources [56]. The World Bank's 2013 Urban Risk Assessment includes recommendations for local stakeholders, such as cities, for a detailed assessment of institutional 
gaps in addressing climate risks [56]. Kreditanstalt für Wiederaufbau (KfW) operates a climate risk screening tool, analysing whether the adaptive capacity (or resilience) of people and eco-systems can be improved [56].

\section{Governance for Sustainability and Inclusive Growth}

This work proposes reflexive governance as an instrument to establish an adaptive and redundant institutional capacity in order to structure resilient infrastructure service provision. The central feature of any resilient network is redundancy [11]. For example, a parallel back-up system must be available in case of network disruption. However, this renewed form of institutional capacity can allow increasing resilience when desired and reducing it when not, according to climate events. This solves an inherent problem of sustainable infrastructure systems, which often aim at system/process maximization and at avoiding resource inefficiencies linked to redundancy [11]. This can enable a successful path towards sustainable development because it avoids unnecessary costs for constructing parallel back-up systems. Therefore, the analysis indicates reflexive governance as essential to unlock the full potential of infrastructure investments following the COVID-19 crisis.

This renewed form of governance also has positive implications for inclusive growth. First, it can improve the access conditions to financial insurance markets by private investors, increasing their confidence in engaging in infrastructure projects in those regions most vulnerable to severe climate events. Lack of access to financial insurance markets is considered a major obstacle in attracting private capital in the least developed countries [27]. Second, in those countries, input from local communities can help in finding a fair balance between investment in resilience and investment in service provision. Indeed, a large financing gap with regard to infrastructure provision still exists, creating a tradeoff in investment decision-making [57].

\section{Discussion}

The analysis carried out in this paper holds true for those countries (both advanced economies and developing countries) implementing economic recovery plans from the COVID-19 crisis, with a focus on infrastructure development. As developing countries are the most vulnerable to climate change, they should take these recommendations carefully. Of course, the implementation of the principles of reflexive governance will be different according to the country's means and resources.

While Hepburn et al. [58] did not identify governance arrangements as a priority in the path towards sustainability within the G20 fiscal recovery packages, existing literature for developing countries does. Bakare [59], analysing the post-COVID-19 infrastructure sector in Nigeria, suggests the human agency theory and to invest in adaptive institutions to cope with future sector vulnerabilities. For South Asia, Madhurima et al. [60] proposed a multi-agents model for environmental risk management and infrastructure resilience. In contrasting future global vulnerabilities, they recommended to consider critical resilient infrastructure as a common public goods and to foster regional cooperation.

Finally, Brousselle et al. [12] corroborated the policy recommendations advanced in this study. In the path towards climate resilience, they suggested to foster innovation in public administrations and to restructure government-civil society relationships. Governance models will need to be adaptive to account for place-specific climate vulnerabilities. This requires leadership from mayors, with the risk of implementing policies conflicting with central governments. Indeed, while climate change hits at the local level, the measures to contrast it are common responsibilities [12].

To summarize, further research is needed to understand how to best conjugate a human-centred model of governance with global macro challenges, such as climate resilience and sustainability. Pioneering case studies would help in providing best practices in the field of governance for climate resilience at the community level, focusing on infrastructure service provision, for instance, following the positive experience of waste banks in developing countries. Case studies will help to identify (i) which actions were taken to promote reflexive governance, (ii) to which extent reflexive governance was applied, (iii) what the positive implications for the provision of public service at the community 
level were, (iv) how infrastructure resilience was strengthened, and (v) if this will lead to positive economic, social and environmental externalities.

Funding: This research received no external funding.

Acknowledgments: I would like to express gratitude to the managing editors and the three anonymous reviewers for their precious feedback.

Conflicts of Interest: The author declares no conflict of interest.

\section{References}

1. Val, D.V.; Yurchenko, D.; Nogal, M.; O'Connor, A. Climate Change-Related Risks and Adaptation of Interdependent Infrastructure Systems. In Climate Adaptation Engineering; Elsevier: Amsterdam, The Netherlands, 2019; pp. 207-242.

2. Vallejo, L.; Mullan, M. Climate-Resilient Infrastructure: Getting the Policies Right; OECD Environment Working Papers, No. 121; OECD Publishing: Paris, France, 2017.

3. United Nations Office for Disaster Risk Reduction (UNDDR). Urgent Need for Disaster Resilient Infrastructure; UNISDR: Geneva, Switzerland, 2018.

4. Bowen, A.; Cochrane, S.; Fankhauser, S. Climate change, adaptation and economic growth. Clim. Chang. 2012, 113, 95-106. [CrossRef]

5. Kreft, S.; Eckstein, D.; Junghans, L.; Kerestan, C.; Hagen, U. Global Climate Risk Index 2015; Briefing Paper; Germanwatch: Berlin, Germany, 2014.

6. Cervigni, R.; Liden, R.; Neumann, J.E.; Strzepek, K.M. (Eds.) Enhancing the Climate Resilience of Africa's Infrastructure: The Power and Water Sectors; The World Bank: Washington, DC, USA, 2015; ISBN 1464804664.

7. D'Adamo, I.; Falcone, P.M.; Martin, M.; Rosa, P. A sustainable revolution: Let's go sustainable to get our globe cleaner. Sustainability 2020, 12, 4387. [CrossRef]

8. OECD. Enhancing Connectivity through Transport. Infrastructure: The Role of Official Development Finance and Private Investment, The Development Dimension; OECD Publishing: Paris, France, 2018.

9. Voß, J.-P.; Borneman, B. The politics of reflexive governance: Challenges for designing adaptive management and transition management. Ecol. Soc. 2011, 16, 9. [CrossRef]

10. Asteria, D.; Santoso, T. Local Action for Waste Bank Management Through an Environmental Communication Strategy and a Collaborative Approach for the Sustainability of Villages. In Competition and Cooperation in Social and Political Sciences; Routledge Taylor and Francis Group: London, UK, 2018.

11. Elmqvist, T.; Andersson, E.; Frantzeskaki, N.; McPhearson, T.; Olsson, P.; Gaffney, O.; Takeuchi, K.; Folke, C. Sustainability and resilience for transformation in the urban century. Nat. Sustain. 2019, 2, 267-273. [CrossRef]

12. Brousselle, A.; Brunet-Jailly, E.; Kennedy, C.; Phillips, S.D.; Quigley, K.; Roberts, A. Beyond COVID-19: Five commentaries on reimagining governance for future crises and resilience. Can. Public Adm. 2020, 63, 369-408. [CrossRef] [PubMed]

13. D'Adamo, I.; Rosa, P. How do you see infrastructure? Green energy to provide economic growth after COVID-19. Sustainability 2020, 12, 4738. [CrossRef]

14. Glass, L.-M.; Newig, J. Governance for achieving the sustainable development goals: How important are participation, policy coherence, reflexivity, adaptation and democratic institutions? Earth Syst. Gov. 2019, 2, 100031. [CrossRef]

15. European Commission. Decision C(2020)6320 of 17 September 2020. Europe in a Changing World-Inclusive, Innovative and Reflective Societies. Horizon 2020, Work Programme 2018-2020. Off. J. Eur. Union 2020, L345-L376. Available online: https://ec.europa.eu/research/participants/data/ref/h2020/wp/2018-2020/main/ h2020-wp1820-societies_en.pdf (accessed on 6 December 2020).

16. European Council. Council Directive 2008/114/EC of 8 December 2008 on the Identification and Designation Of European Critical Infrastructures and the Assessment of the Need to Improve Their Protection. Off. J. Eur. Union 2008, L345-L375. Available online: https://eur-lex.europa.eu/LexUriServ/LexUriServ.do?uri=OJ:L: 2008:345:0075:0082:EN:PDF (accessed on 6 December 2020).

17. Tvaronavičienè, $\mathrm{M}$. Towards internationally tuned approach towards critical infrastructure protection. J. Secur. Sustain. Issues 2018, 8, 143-149. [CrossRef] 
18. Forzieri, G.; Bianchi, A.; e Silva, F.B.; Marin Herrera, M.A.; Leblois, A.; Lavalle, C.; Aerts, J.C.J.H.; Feyen, L. Escalating impacts of climate extremes on critical infrastructures in Europe. Glob. Environ. Chang. 2018, 48, 97-107. [CrossRef]

19. Pursiainen, C. Critical infrastructure resilience: A Nordic model in the making? Int. J. Disaster Risk Reduct. 2018, 27, 632-641. [CrossRef]

20. Murdock, H.J.; de Bruijn, K.M.; Gersonius, B. Assessment of critical infrastructure resilience to flooding using a response curve approach. Sustainability 2018, 10, 3470. [CrossRef]

21. Yang, Y.; Ng, S.T.; Xu, F.J.; Skitmore, M. Towards sustainable and resilient high density cities through better integration of infrastructure networks. Sustain. Cities Soc. 2018, 42, 407-422. [CrossRef]

22. OECD. Good Governance for Critical Infrastructure Resilience, OECD Reviews of Risk Management Policies; OECD Publishing: Paris, France, 2019.

23. Baubion, C. System Thinking for Critical Infrastructure Resilience and Security. In Proceedings of the Joint OECD-JRC Workshop Report, Paris, France, 24-25 September 2018.

24. Christopher, H. Bovis risk in public-private partnerships and critical infrastructure. Eur. J. Risk Regul. 2017, 6, 200-207.

25. Wojewnik-Filipkowska, A.; Wȩgrzyn, J. Understanding of public-private partnership stakeholders as a condition of sustainable development. Sustainability 2019, 11, 1194. [CrossRef]

26. Miller, A.; Swann, S. How to Make Infrastructure Climate Resilient; EMCompass, Brief Paper No. 14; International Finance Corporation: Washington, DC, USA, 2016.

27. Sundararajan, S.; Suriyagoda, N. Climate Risks and Resilience in Infrastructure PPPs: Issues to be Considered; Issue Brief; Public Private Infrastructure Advisory Facility (PPIAF): Washington, DC, USA, 2016.

28. Karanasios, K.; Parker, P. Tracking the transition to renewable electricity in remote indigenous communities in Canada. Energy Policy 2018, 118, 169-181. [CrossRef]

29. Wegrzyn, J.; Gluszak, M.; Telega, A. Infrastructure endowment, financial constraints and willingness to engage in PPPs: The case of Poland. Public Money Manag. 2019, 39, 132-138. [CrossRef]

30. Meadowcroft, J. What about the politics? Sustainable development, transition management, and long term energy transitions. Policy Sci. 2009, 42, 323-340. [CrossRef]

31. Voß, J.P.; Smith, A.; Grin, J. Designing long-term policy: Rethinking transition management. Policy Sci. 2009, 42, 275-302. [CrossRef]

32. Boin, A.; McConnell, A. Editorial: Unravelling the Puzzles of Critical Infrastructures. J. Conting. Crisis Manag. 2007, 15, 1-3. [CrossRef]

33. Crichton, M.T.; Ramsay, C.G.; Kelly, T. Enhancing organizational resilience through emergency planning: Learnings from cross-sectoral lessons. J. Conting. Crisis Manag. 2009, 17, 24-37. [CrossRef]

34. Goldthau, A. Rethinking the governance of energy infrastructure: Scale, decentralization and polycentrism. Energy Res. Soc. Sci. 2014, 1, 134-140. [CrossRef]

35. Feindt, P.H.; Weiland, S. Reflexive governance: Exploring the concept and assessing its critical potential for sustainable development. Introduction to the special issue. J. Environ. Policy Plan. 2018, 20, 661-674. [CrossRef]

36. Mees, H.; Alexander, M.; Gralepois, M.; Matczak, P.; Mees, H. Typologies of citizen co-production in flood risk governance. Environ. Sci. Policy 2018, 89, 330-339. [CrossRef]

37. Westling, E.L.; Sharp, L.; Rychlewski, M.; Carrozza, C. Developing adaptive capacity through reflexivity: Lessons from collaborative research with a UK water utility. Crit. Policy Stud. 2014, 8, 427-446. [CrossRef]

38. Koester, V. The Convention on Access to Information, Public Participation in Decision-Making and Access to Justice in Environmental Matters (Aarhus Convention). In Making Treaties Work: Human Rights, Environment and Arms Control; Cambridge University Press: Cambridge, UK, 2007; ISBN 9780511494345.

39. Rotmans, J.; Loorbach, D.; Kemp, R. Transition Management: Its Origin, Evolution and Critique. In Proceedings of the Workshop on Politics and Governance in Sustainable Socio-Technical Transitions, Berlin, Germany, 19-21 September 2007.

40. Kemp, R.; Loorbach, D. Transition Management: A Reflexive Governance Approach. In Reflexive Governance for Sustainable Development; Edward Elgar: Cheltenham, UK, 2006.

41. Decision of the President of the European Commission on the Appointment of Members to the Task Force on Subsidiarity, Proportionality and "Doing Less More Efficiently", C(2018) 406; European Commision: Brussels, Belgium, 2017. 
42. McPhearson, T. Urban Futures: Transforming Cities for Resilience and Sustainability. 2018. Available online: https: //www.elon.edu/u/news/2019/11/05/mcphearson-brings-climate-warnings-scientific-progress-to-elon/ (accessed on 1 October 2020).

43. Bai, X.; McAllister, R.R.J.; Beaty, R.M.; Taylor, B. Urban policy and governance in a global environment: Complex systems, scale mismatches and public participation. Curr. Opin. Environ. Sustain. 2010, 2, 129-135. [CrossRef]

44. Kumaraswamy, M.; Zou, W.; Zhang, J. Reinforcing relationships for resilience-by embedding end-user 'people' in public-private partnerships. Civ. Eng. Environ. Syst. 2015, 32, 119-129. [CrossRef]

45. Junqi, Z. Developing public private people partnership (4P) for post disaster infrastructure procurement. Int. J. Disaster Resil. Built Environ. 2015, 6, 468-484. [CrossRef]

46. Majamaa, W. The 4th P-People-in Urban Development Based on Public-Private-People Partnership. Ph.D. Thesis, Helsinki University of Technology, Helsinki, Finland, 2008.

47. Jahangiri, K.; Izadkhah, Y.O.; Tabibi, S.J. A comparative study on community-based disaster management in selected countries and designing a model for Iran. Disaster Prev. Manag. 2011, 20, 82-94. [CrossRef]

48. The World Bank. What a Waste: An Updated Look into the Future of Solid Waste Management. 2018. Available online: www.worldbank.org/en/news/immersive-story/2018/09/20/what-a-waste-an-updatedlook-into-the-future-of-solid-waste-management (accessed on 1 October 2020).

49. Winne, S.; Horrocks, L.; Kent, N.; Miller, K.; Hoy, C.; Benzie, M.; Power, R. Increasing the Climate Resilience of Waste Infrastructure. Final Report under Defra Contract ERG 1102. Available online: https://assets.publishing.service.gov.uk/government/uploads/system/uploads/attachment_data/file/ 183933/climate-resilience-full.pdf (accessed on 6 December 2020).

50. Bovaird, T.; Loeffler, E. The Role of Co-Production for Better Health and Wellbeing: Why We NEED to Change; Governance International: Birmingham, UK, 2013; ISBN 9780957253322.

51. Colding, J.; Barthel, S. The potential of "Urban Green Commons" in the resilience building of cities. Ecol. Econ. 2013, 86, 156-166. [CrossRef]

52. Buijs, A.E.; Mattijssen, T.J.; Van der Jagt, A.P.; Ambrose-Oji, B.; Andersson, E.; Elands, B.H.; Steen Møller, M. Active citizenship for urban green infrastructure: Fostering the diversity and dynamics of citizen contributions through mosaic governance. Curr. Opin. Environ. Sustain. 2016, 22, 1-6. [CrossRef]

53. Wehn, U.; Rusca, M.; Evers, J.; Lanfranchi, V. Participation in flood risk management and the potential of citizen observatories: A governance analysis. Environ. Sci. Policy 2015, 42, 187-198. [CrossRef]

54. Global Resilient Cities Network. Available online: www.rockpa.org/project/global-resilient-cities-network/ (accessed on 1 October 2020).

55. Runde, D.F.; Ramanujam, S.R. Financing and Implementing the Quality Infrastructure Agenda: Leveraging the United States-Japan Partnership to Ensure a High.-Quality Option and Other Next Steps; Report; Center for Strategic and International Studies: Washington, DC, USA, 2018.

56. Ricardo-AEA. Climate Related Standards and Measures for Assessing Investments in Infrastructure Projects; Ricardo-AEA: Harwell, UK, 2013.

57. OECD Development Center. Quality Infrastructure for Development; OECD Development Center: Paris, France, 2018.

58. Hepburn, C.; O'Callaghan, B.; Stern, N.; Stiglitz, J.; Zenghelis, D. Will COVID-19 fiscal recovery packages accelerate or retard progress on climate change? Oxf. Rev. Econ. Policy 2020, 36, S359-S381. [CrossRef]

59. Bakare, H.O. Regional Planning for Resilient And Sustainable Post-Covid-19 Recovery and Transport Infrastructure Transformation in Nigeria. In Proceedings of the Special Virtual Conference on Covid-19 Theme: Geographers and Post Covid-19, Held via Zoom, 29-30 June 2020.

60. Madhurima, S.; Sanjay, S. When COVID-19 and Natural Hazards Collide: Building Resilient Infrastructure in South Asia; Issue Brief; No. 413; Observer Research Foundation (ORF): New Delhi, India, 2020.

Publisher's Note: MDPI stays neutral with regard to jurisdictional claims in published maps and institutional affiliations. 